\title{
INTERIOR DESIGN IN THE RESTORATION OF THE NATIONAL MUSEUM OF PLASTIC ARTS OF MOLDOVA
}

\author{
Liliana Platon, ORCID ID: 0000-0002-8458-1601 \\ Technical University of Moldova, 168 Ștefan cel Mare blvd., Chisinau, Republic of Moldova \\ *Coresponding autor: Liliana Platon, liliana.platon@udu.utm.md
}

Received: 08. 29. 2021

Accepted: 10. 02. 2021

\begin{abstract}
This paper presents a scientific analysis of interior design in the restoration process of the National Museum of Arts of Moldova. The interior design segment is historically researched through the genre of architecture, from the historical compartment of the XIX-XX century. In the same context, several works of various architects who designed important constructions in Kishinev are analyzed. The study highlights the role and responsibility of interior design in the process of restoration and capitalization of the national cultural heritage. It also analyzes the correspondence or synchronization of new implementations in design with the stylistic concept achieved in the historical period.
\end{abstract}

Keywords: aesthetics, heritage, renovation, restoration, space, style.

Rezumat. Lucrarea prezintă o analiză științifică a designului interior din cadrul procesului de restaurare a Muzeului Național de Artă a Moldovei. Segmentul de design interior este cercetat sub aspect istoric prin intermediul genului arhitectură, din compartimentul istoric al secolului XIX - XX. În același context sunt analizate mai multe operele ale diverșilor arhitecți care au proiectat construcții importante în Chișinău. Studiul scoate în evidență rolul și responsabilitatea designului interior în procesul de restaurare și valorificare a patrimoniului cultural național. Deasemeni se analizează corespunderea sau sincronizarea noilor implementări în design cu conceptul stilistic realizat în perioada iostorică.

Cuvinte cheie: estetic, patrimoniu, renovare, restaurare, spațiu, stil.

\section{Introduction}

The National Museum of Plastic Arts of Moldova is an architectural symbol of major importance for national culture and art. The Museum Building (hereinafter NMPAM) is a historical monument of national heritage, remarkable both for the architectural character of its construction and for its contribution to the artistic atmosphere in the country. The current Museum has a very interesting history: "the urban mansion hosted the girls' high school of Princess Dadiani, built in 1901 according to the plans of the architect Alexandru Bernardazzi, and then, in Soviet times, it had several functionalities, because, in the end, after the abolition of the museum of the communist party, to become the main headquarters of NMPAM "[1]. 
After a very long and futile process of restoration and rehabilitation works of the museum, the Republic of Moldova benefited amazingly from the support of the Romanian government which financed the consolidation and restoration of the museum's "Dadiani" headquarters (NMPAM). The works continued over 11 years and were successfully completed in November 2016. Today "the building has acquired its original shape" created in the period of 1901 [2].

Visiting the halls of the National Museum of Plastic Arts in Kishinev we are deeply impressed by the aesthetic values, skill and artistic culture of interior architecture. Based on the general concept of preserving the original architectural elements in the reconstruction of the museum building, we direct the given research on the principles of aesthetic formulation and cultural-artistic trends in architecture of the late nineteenth and early twentieth centuries. The study of historical evolution will determine exactly the area of artistic implementations in exterior and interior architecture, stating the character and stylistic concepts of buildings during the study period and the contribution of architects on urban evolution [3, p. 3].

\section{Kishinev architecture at the end of the XIX th century and the beginning of the $X X$ century}

In order to discern the constructive and stylistic predilections in the practice of interior design from the beginning of the $\mathrm{XX}$ century, it is necessary to analyze the general segment or genre of architecture, because the approach to the interior was and is a component of architecture. The term "design" is known in professional language more in the contemporary period, although it has a long history, coming from the Latin verb "designation" [4, p. 5]. The main significance of the design remains the aesthetic design, which designate the complex process of conception and design of functional and beautiful forms at the same time, according to the demands of the present time. [5, p. 136]. Interior design develops and manifests itself through the same aesthetic predilections common to the general sphere of architecture [6, p. 57].

Analyzing the evolution of architecture on the territory of the Republic of Moldova, we notice that at the end of the XIII and the beginning of the XIX century constructions are made in a neoclassical language associated with the Russian "Russian classicism" found mostly in religious places of worship [7, p. 70 - 71]. The neoclassical approach is completed with elements of the classical Greek orders, strictly and generally ordering the constructions. Later, in the middle of the XIX century, when the architecture of Kishinev experienced an intense urban development [8, p. 79], the first implementations of modern styles appeared, advancing nicely towards the beginning of the $X X$ century $[9, p .20]$. A stylistic polyphony appears in the urban landscape by applying historical-ethnic data, among which the consecutive trends of: "architectural romanticism", "baroque" with the interweaving of "Renaissance and Gothic" motifs, gradually resorting to the stage of "enrichment" of decorative combinations in aesthetics buildings, observed in an evolutionary consistency until around the twentieth century $[10$, p. 5].

At the turn of the centuries (XIX-XX) the architecture of Chisinau marks a period of transition from eclectic implementations to Art Nouveau (1900-1910), revealing some oriental motifs in the decoration of buildings (Zemstva Museum, the house of MV Karcevski and others.) [11]. At the same time (early twentieth century), the aesthetic formula of many buildings retains neoclassical, neo-Gothic elements and so-called "neo-Russian" 
implementations - specific through the decorative details typical of Russian architecture [12, p. 21]. This category is also known as the "brick style" or "rational" constructions made mostly of white limestone without plaster and carved decoration on facades in favor of "decorating the brick ornament" [3, p. 11]. This aesthetic is found in many buildings in Bessarabia [8].

The list of new modern constructions includes the Penitentiary Building (Prison Fortress) in Kishinev (1843 - 1863) by the architect F. Frapolli, the urban mansion of RâșcanuDerojinschi by Al. Bernardazzi, Vila Mimi (1880) by lacov A. Uscat, Boys' Gymnasium no. 1 (1888), District Court (1887) and that of the Assembly of the Nobility in Kishinev (1889) by the Austrian architect Heinrich von Lonsky, Royal School (currently the main block of the State University), the Girls' Gymnasium of Zemstva (1881 - 1882) and the Theological School (1873) by Heinrich von Lonsky and Mihail S. Serotinsky, the Water Towers or the Urban Aqueduct (1890), the Theological Seminary XX) by V.M. Elkașev, Duma and City Public Administration (1900) and others by Chekerul-Kush M. [14], Mitrofan A. Elladi and Al Bernardazzi, Mitrofan A. Elladi Commercial School, Diocesan House, Land Bank (1910 - 1911) after the project of the diocesan architect G.V. Cupcea, The building of the former Community of Charity Sisters from Hârbovăț Monastery (1904-1905), by Vladimir N. Țâganco and many other buildings designed and built by many important architects who contributed to the formation of modern stylistic architecture in Bessarabia [10].

An important impact on the architectural-urban evolution of Kishinev had the architect Alexandru or Alessandro Bernardazzi (02.07.1831 - 14.08.1907), who from 1856 to 1878 was the main person responsible for the urban construction [15, p. 25]. The architect distinguished himself by a "completely new new experience in the context of the reform of cultural diffusion" [3, p. 3]. In its activity was designed and built the second Gymnasium for girls and the chapel of the gymnasium founded by Princess N. Dadiani (from 31 August 1989, no. 115) [13, p. 58]. His aesthetic predilections are based on elegant associations between white limestone masonry and reddish brick, the monumental design of doors and windows, the rhythmic repetitions of shapes, the simplicity of details and the complexity of constructions, which attest to the influences of Italian Gothic. [15, p. 35].

The contribution of these masters in the architecture of Kishinev favored the development of the city at a higher artistic level, becoming "one of the most beautiful in South-Eastern Europe". [3 , p. 3].

\section{Interior design in the NMPAM restoration process}

Interior design or arrangement of interior architecture is usually carried out in accordance with the architecture of the building and the aesthetics of the facades. The interior of the National Museum of Art is no exception and according to historical data demonstrates a stylistic synchronization with the aesthetic sumptuousness of the facade. This is confirmed in the literature which highlights the descriptive data: „the spacious hall, the magnificent, spectacular or elegant character of the stairs, the immense brightness and spatiality, seem to announce the perfect distribution of the spaces in the huge classrooms. The wide halls, the high ceilings of the classrooms, highlight the interest in ensuring good conditions for students" [15, p. 35] (Figure 1, 2).

The interior space, as well as the facade of the building, is well coordinated compositionally through the monumentally geometrical constructive elements, along with the configuration of doors and windows - made in a Renaissance manner. 


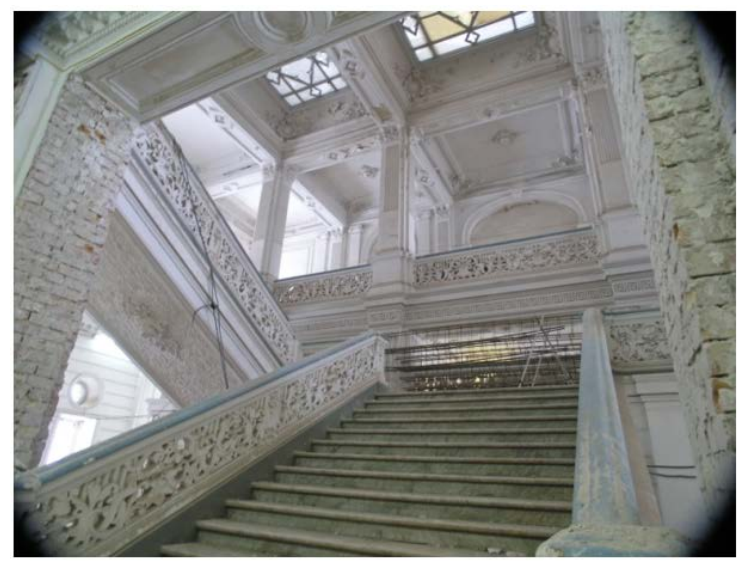

Figure 1. Stairs of the

headquarters to the reconstruction of the

National Museum of Plastic Arts of Moldova.

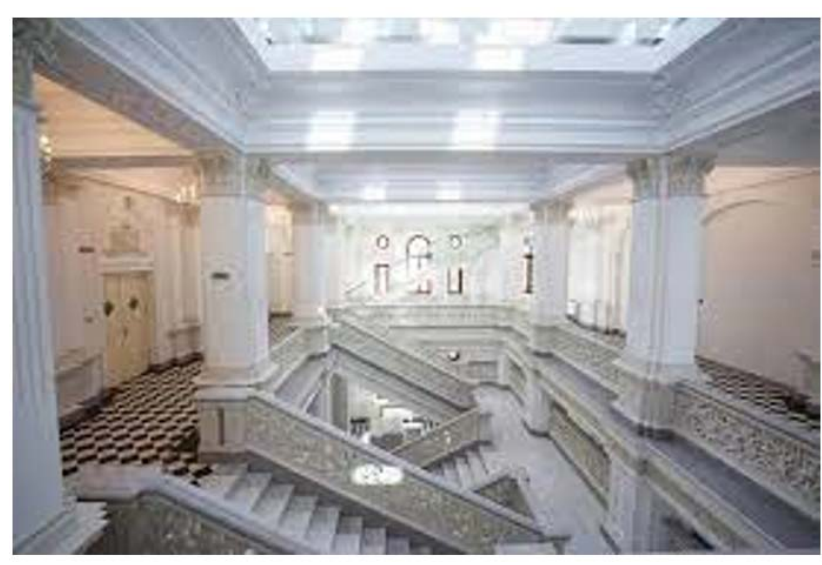

Figure 2. Stairs of the headquarters after the reconstruction of the National Museum of Plastic Arts of Moldova.

The shapes of the windows are paired, consisting of small dimensions, finished in the upper part by arches, adorned with Gothic weave [10, p. 21] (Figure 3 (a, b, c)). The aesthetic formula of the space is balanced by the massive generalized shapes and decorative plastic that bring an extra delicacy and elegance to the entourage. From historical data (Figure 1) the walls of the rooms were lacking in some places decorative details and allowed to see the structure of white stone masonry, combined with burnt brick, thus following an association with the exterior of the building (Figure 4 (a)).

At the same time, the modeling of the railings and the connections between the ceiling surfaces included a unique ornamental delicacy, which demonstrated the involvement of eclectic and Art Nouveau [12, p. 18], stylistics (Figure 4 (b, c)).

The given implementations are found in the aesthetic interest of the construction because, as the researcher Igor Pecarschi mentions, the construction is "an important monument of the transition period from eclectic to Art Nouveau" [10, p. 20].

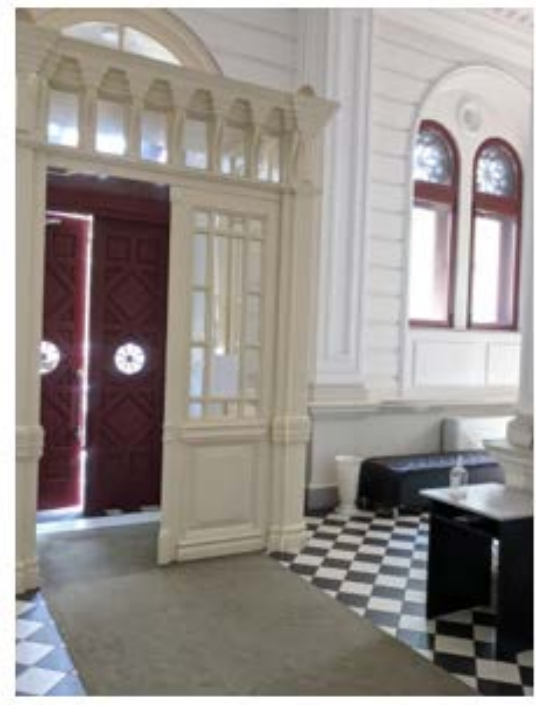

a)

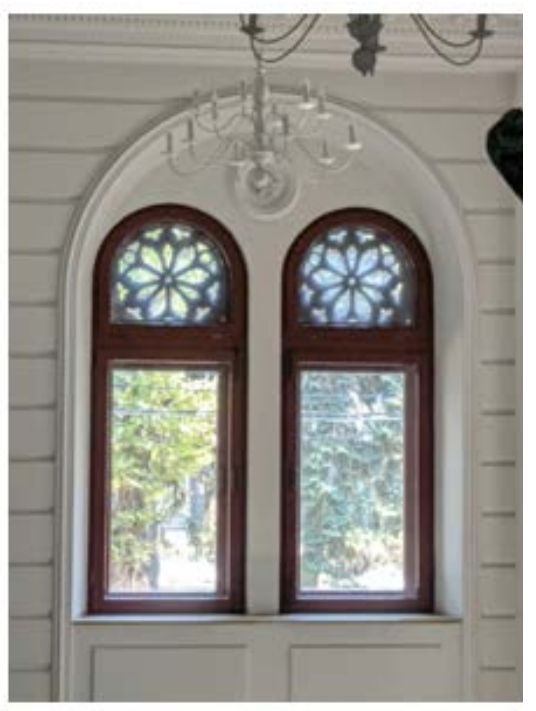

b)

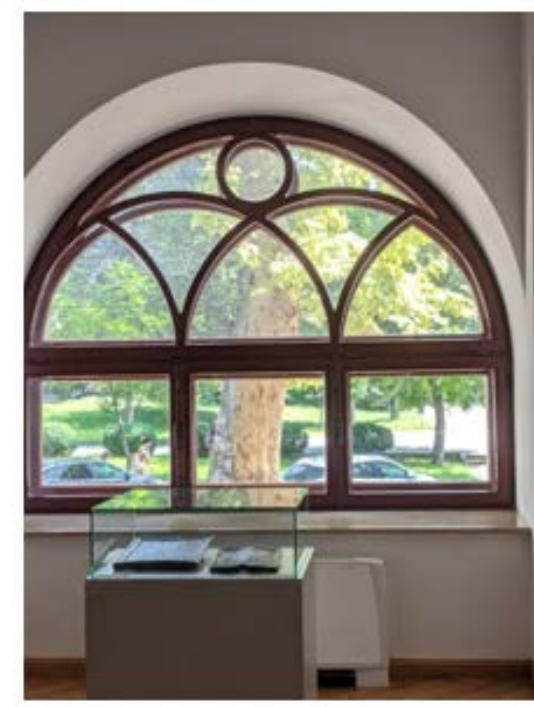

c)

Figure 3. Configuration of windows in the current National Museum of Plastic Arts of Moldova. 


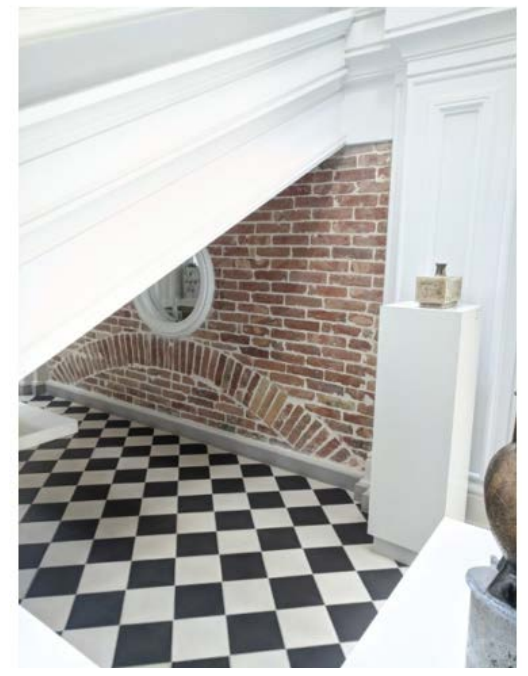

a)

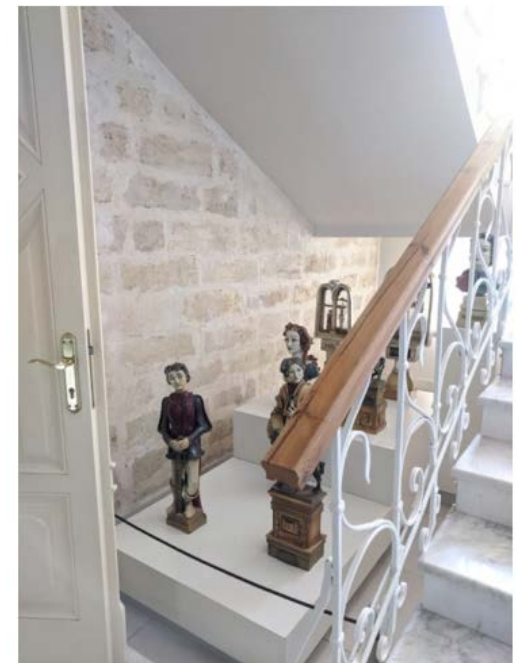

b)

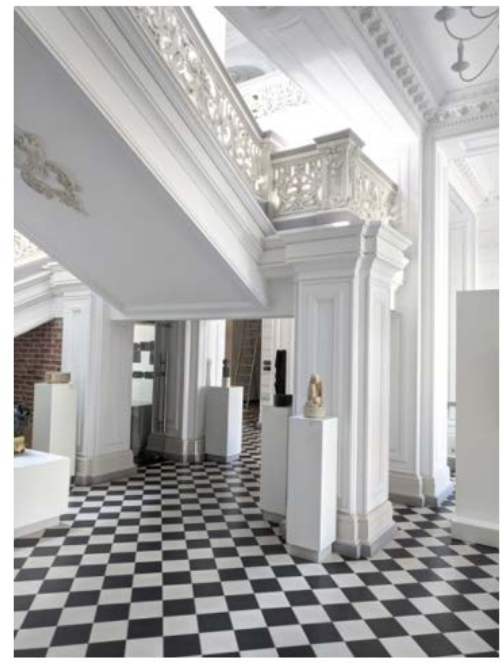

c)

Figure 4. Combinations of materials and plastic invoices in the current National Museum of Plastic Arts of Moldova.

By definition Art Nouveau or Art 1900, it seeks "a synthesis of all the arts as a response to eclecticism and an international style" [16, p. 29). According to the known data for the initiation of the researched construction (1901), it can be seen that in the first years of the early XX century interior design in Bessarabia experienced a modern evolution, extremely refined, synchronized with contemporary European trends, and free and very sensitive management. of these artistic tendencies in the inner entourage speak of an evolved noble culture present in the intellectual environment of the country.

The restoration of the current Museum of Fine Plastic in Kishinev (headquarters) carried out over eleven years (until 2016), after the project of architect George Bulat, primarily aimed at renovating specific traditions of national architecture from the early twentieth century (1901), demonstrated in this building. The works were carried out to correspond as closely as possible to the historical prototype of the building (Figure $5(a, b)$ ). Fully respecting the historical reminiscences of the interior: eclectic ornamentation, baroque medallions, columns, Greek meanders, Art Nouveau chandeliers, etc., however, the contemporary architect involves in a very subtle way some postmodern solutions.

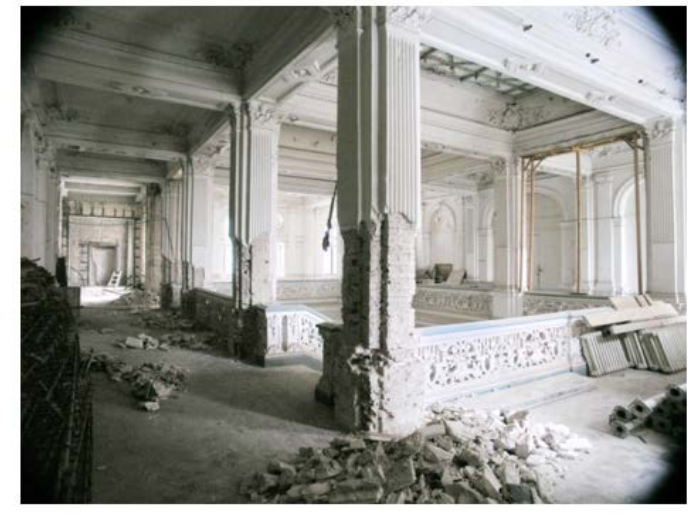

a)

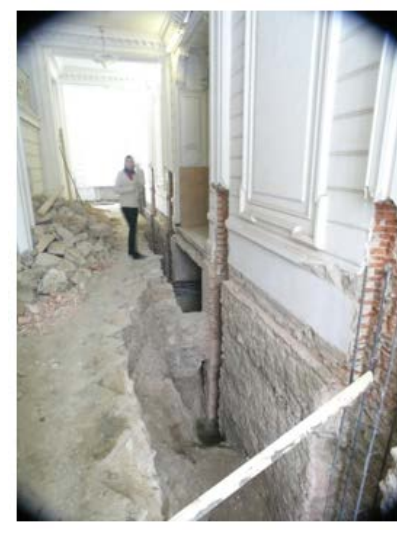

b)

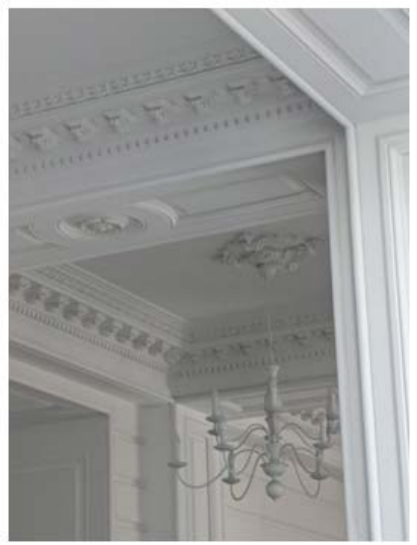

c)

Figure 5. $(a, b)$ Restoration works in the National Museum of Plastic Arts of Moldova; (c) Stylistic combinations in the ornamental decoration of the National Museum of Plastic Arts of Moldova. 
Fully respecting the historical reminiscences of the interior: eclectic ornamentation, baroque medallions, columns, Greek meanders, Art Nouveau chandeliers, etc., however, the contemporary architect involves in a very subtle way some postmodern solutions.

These can be seen in the constructive decisions of the stairs, the materials used to complete them, the construction on the second level of the headquarters, etc., which bring an imprint of the current time in combination or complementing the historical values of the national heritage (Figure 5 (c)).

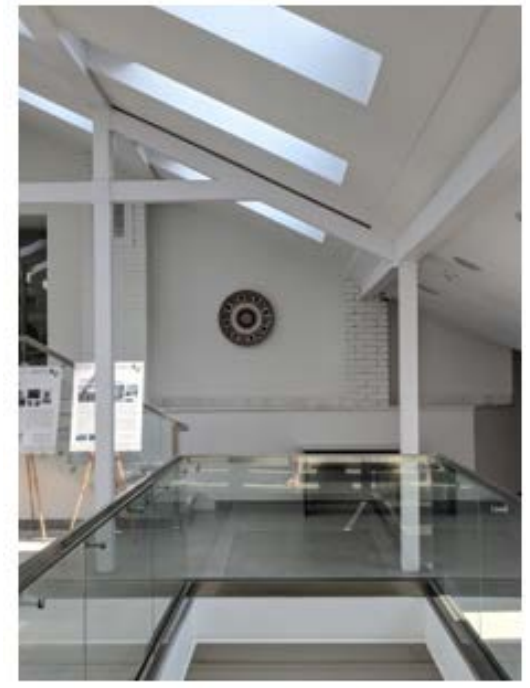

a)

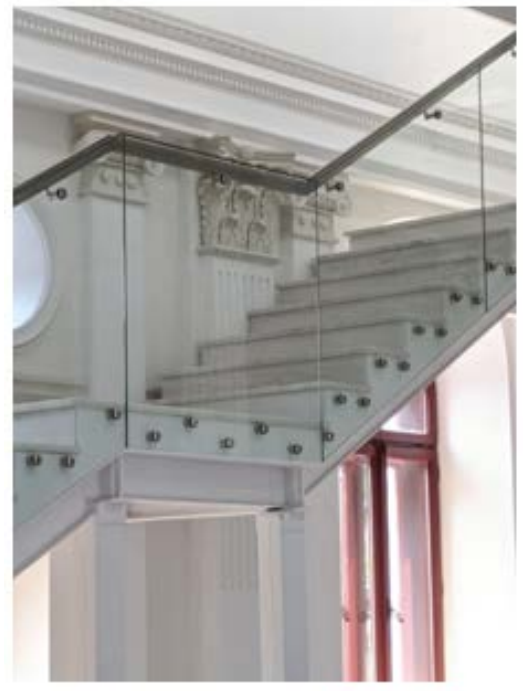

b)

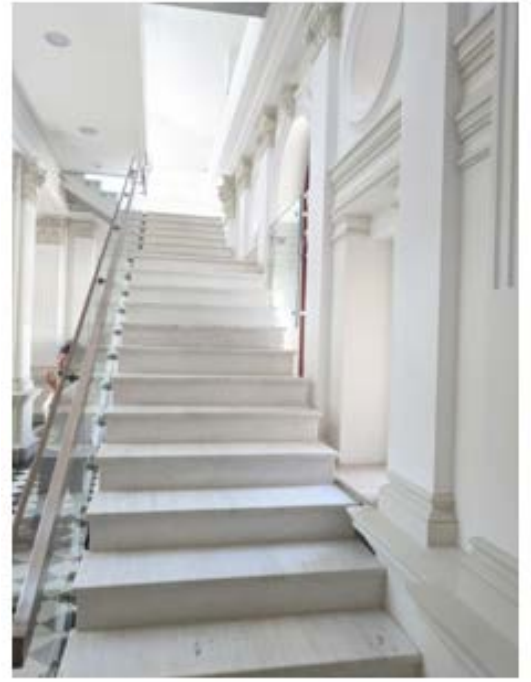

c)

Figure 6. $(a, b, c)$ Modern-contemporary implementations in the restoration of the National Museum of Plastic Arts of Moldova.

The solutions proposed in the interior design of the Museum provide at the same time the preservation, capitalization of historical data and their coordination with the current norms of interior design. The harmonious arrangement of the contemporary interior aims at the optimal realization of various problems: rational use of space, ensuring circulation, sufficient lighting, sound insulation, ergonomic solution of furniture, creating a favorable climate, ensuring appropriate color combinations, judicious use of textiles, reasonable involvement of aesthetic decoration, etc. [15, p. 128]. All these elements have been skillfully analyzed and solved inside the current interior of the Museum, additionally using the most advanced air conditioning systems, safety and security of the rooms in accordance with the moderate global provisions for such buildings (Figure $6(a, b, c)$ ). Following the reconstruction works, a refined aesthetic ambiance was obtained, extremely luxurious, elegant and at the same time true to the historical prototype, much improved by the constructive, engineering and modern aesthetic possibilities, which ensure a noble resonance to the historic building.

\section{Conclusions}

The Museum of Plastic Arts of Moldova after the restoration works is brought back into the cultural-artistic view of the country. The aesthetic data of the interior and exterior architecture of the building speak of a high socio-cultural level existing in the Bessarabian environment at the junction of the 19th and 20th centuries. In the process of restoring the national heritage, interior design occupies an important place, assuming the responsibility of restoring the constructive and aesthetic values of historical architecture. At the same time, the interior design project resorted to a process of correlating historical traditions with 
contemporary ones, involving current solutions in finishing techniques, construction materials, plastic modeling of current forms and norms in the field. The plastic approach of the interior design respectfully preserves the incipient stylistic formula of the building, completing at the same time the aesthetic concept through associated modern and postmodern interventions.

Following the famous restoration of the National Museum of Plastic Arts of Moldova, thanks are due to the Romanian Government, the Ministry of Culture of Moldova, then Minister of Culture Monica Babuc, the director of the Tudor Zbârnea Museum, the architect George Bulat and all those involved in this work.

\section{Bibliography}

1. Contrafort nr. 1-2 (257-258). Muzeul Național de Arte Plastice din Chișinău sau despre miracolul unei restaurări (dialog cu pictorul Tudor Zbârnea, director MNAP), 1-2 2017, [online] [accesat 28.07. 2021] Disponibil http://www.contrafort.md/categorii/muzeul-na-ional-de-arte-plastice-din-chi-u-sau-despremiracolul-unei-restaur-ri-dialog-cu-

2. Madein.md. Noutăți. La Chișinău, după 11 ani de restaurare a fost deschis Muzeul Național de Artă. Foto. [online] [accesat 28.07. 2021] Disponibil https://www.madein.md/news/arta-si-manufactura/la-chisinaudupa-11-ani-de-restaurare-a-fost-deschis-muzeul-national-de-arta-foto

3. Catalog of the exhibition „Dynasty of Bernardazzi Architects” Chisinau, 2002. 27 p.

4. Rădoi A. Salvarea omenirii de la poluarea fizică, estetică și morală, impune ca mileniul al treilea să fie: Mileniul designului. Timișoara: Imprimeria Mirton, 1996, 200 p.

5. Platon L. Designul produsului. În Conferința tehnico-științifică internațională „Probleme actuale ale urbanismului și amenajării teritoriului", ediția a V-a. Chișinău: FUA, UTM, 2010. pp. 135-138.

6. Prus E. Monumentele arhitecturale ca referenți ai textului artistic. Revista Arta 2002, Chișinău: Institutul Patrimoniului Cultural, 2002. pp.57-58.

7. Ceastina A. Arhitectorî bessarabii. Chișinău: Garomont studio, 2018, 384 p.

8. Nesterov T., Vatamaniuc A. Istoria deschisă a planului de sistematizare postbelică a Chișinăului. Revista Arta 2019, Chișinău: Institutul Patrimoniului Cultural, 2019. pp.78-84.

9. Ceastina A. Creația arhitecților din Basarabia în prima jumătate a secolului al XIX-lea. Autoreferatul tezei de doctor în studiul artelor și culturologie. Chișinău, 2016. 30 p.

10. Pecarschi I. Edificii publice din Chișinău din perioada eclecticii și art nuvo. Chișinău: Ex-Libris, 2010. 31 p.

11. Ceastina A. Architecture and Sculpture of the City Garden in Kishinev for the XIX Century (For the 200th anniversary of the Ștefan cel Mare Park in Chisinau). Revista Arta 2018, Chișinău: Institutul Patrimoniului Cultural, 2018. pp.32-39.

12. Stavilă T. Arta plastică modernă din Basarabia 1887-1940. Chișinău: Știința, 2000. 159 p.

13. Nesterov T. Monumente de arhitectură din Chișinău - între autenticitate și improvizare postbelică. ). Revista Arta 2018, Chișinău: Institutul Patrimoniului Cultural, 2018. pp.53-61.

14. Ceastina A. Architect Mikhail Chekerul-Kush (1865-1917) anud his main project of the Kishinev city public bank. Revista Arta 2019, Chișinău: Institutul Patrimoniului Cultural, 2019. pp.36-41.

15. Bubis I.M. Zodcie Bernardazzi. Chișinău, Moldova/ Louisville, Kentucky USA, 1997. 108 p.

16. Florea V., Szekely Gh. Mică enciclopedie de arta universala. Bucuresti: Litera international, 2005. 499 p. 